\title{
PENERAPAN METODE SCRAMBLE UNTUK MENINGKATKAN PRESTASI BELAJAR SKI KELAS V MI AL-IMAN SOROGENEN
}

\author{
Ani Muflihah dan Khanif Maksum \\ Prodi PGMI STIA Alma Ata Yogyakarta \\ Email:khanifmaksum@gmail.com
}

\begin{abstract}
This study aims to determine the planning scramble method is applied in teaching Islamic Cultural History (SKI), to determine the feasibility of the methods scramble on the subjects of Cultural History of Islam and this research is also expected to improve student achievement in grade VMI Al-Iman Sorogenen.

This type of research is the Classroom Action Research (Classroom Action Research) conducted in MI Al-Iman Sorogenen. This study uses two cycles of learning with two meetings in the first cycle, and the first meetings on the second cycle. The method used to scramble method is applied with a group discussion on the cycle I and II. In the discussions, the students were divided into small groups resulting in effective information exchange among members.

The results showed that the planning of the use of methods scramble on learning SKI class VMI Al-Iman Sorogenen running smoothly starting from the manufacture of Learning Implementation Plan (RPP), card making questions and answer cards, make sheets of pre-test and post-test, and make the observation sheet, Scramble method can also be implemented and applied in teaching Islamic Cultural History, with the effect size of 7.3. Improved student achievement showes the average value of pre test cycle I is 46.6\% increase in post test becomes 53.33\%. While in the second cycle showed an increase learning achievement of the average value of pre-test $53.33 \%$ increase in post-test to 80\%. Thus, an increase learning achievement SKI class V MI Al-Iman Sorogenen based on the results of post test is $26.7 \%$.
\end{abstract}

Keyword: scramble method, achievement

\section{PENDAHULUAN}

Sejarah dipahami sebagai cerita masa lalu, mempunyai akar yang menjadi asal muasal peristiwa atau sumber kejadian yang begitu penting sampai dikenang sepanjang waktu. ${ }^{1}$ Dari penjelasan di atas, Sejarah Kebudayaan Islam bisa

${ }^{1}$ Hanafi, Pembelajaran Sejarah Kebudayaan Islam, (Jakarta: Direktorat Jenderal Pendidikan Islam Depag RI, 2009), hlm. 4. 
dipahami sebagai suatu cerita peristiwa masa lalu yang mempunyai asal-muasal tertentu.

Didalam kegiatan sekolah, hal yang paling pokok adalah kegiatan belajar mengajar. Tercapai atau tidaknya suatu tujuan pembelajaran, tergantung bagaimana proses belajar yang dialami oleh peserta didik. Sistem pembelajaran yang terlaksana di MI Al-Iman Sorogenen untuk mata pelajaran Sejarah Kebudayaan Islam (SKI) kebanyakan hanya menggunakan metode ceramah. Walaupun sudah diterapkan metode lain seperti tanya jawab, akan tetapi pembelajaran tersebut masih kurang optimal.

Salah satu penyebab rendahnya prestasi siswa kelas V MI Al-Iman Sorogenen dalam belajar SKI adalah karena terlalu banyak materi yang diajarkan kebanyakan menggunakan metode ceramah dan siswa menjadi kurang bersemangat dalam menerima pelajaran kalau tidak ada variasi metode. Kebanyakan aktivitas siswa hanya mendengar dan mencatat dan tidak mendapat kesempatan untuk berfikir lebih dalam.

Ketika belajar secara pasif, peserta didik mengalami proses tanpa rasa ingin tahu, tanpa pertanyaan dan tanpa daya tarik pada hasil (kecuali, barangkali, sekadar sertifikat yang dia akan terima). Ketika belajar secara aktif, pelajar mempunyai sesuatu. Dia ingin menjawab pertanyaan, memerlukan informasi untuk menyelesaikan masalah, atau menyelidiki cara untuk melakukan pekerjaan. ${ }^{2}$

Berdasarkan hasil observasi awal yang dilakukan di MI Al-Iman Sorogenen ditemukan beberapa permasalahan dalam kegiatan belajar mengajar mata pelajaran SKI, salah satunya adalah metode mengajar yang digunakan oleh guru MI AlIman Sorogenen yang kurang bervariasi. Proses belajar mengajar masih banyak didominasi oleh guru karena dalam penyampaian materi ini, guru lebih banyak menggunakan metode ceramah sehingga siswa cenderung pasif di kelas. Siswa juga hanya sebagai pendengar dan pencatat saja. Materi sejarah lebih banyak disampaikan dengan metode ceramah menyebabkan siswa mempunyai anggapan bahwa pelajaran sejarah adalah pelajaran menghafal yang membosankan. Anggapan ini sangat mempengaruhi terhadap prestasi belajar siswa.

Metode ceramah memang menguntungkan bagi guru karena semua materi yang banyak bisa tersampaikan secara cepat dan hemat waktu, tetapi dari pihak anak menjadi kurang menguasai materi dan peserta didik cenderung bosan dengan metode seperti itu. Akibatnya adalah prestasi mereka kurang bisa ditingkatkan. Sebenarnya metode ceramah memang selalu dibutuhkan untuk penyampaian materi, tetapi sebaiknya metode ceramah tidak digunakan

${ }^{2}$ Mel Silberman, Active Learning: 101 Strategi Pembelajaran Aktif, Terjem. Oleh Sarjuli, dkk, Cet. Ke-3, (Yogyakarta: Yappendis, 2005), hlm. 5. 
untuk menyampaikan keseluruhan materi. Jadi harus dikolaborasikan dengan metode-metode yang lain.

Seorang guru harus memiliki strategi agar anak didik dapat belajar efektif dan efisien untuk bisa mencapai tujuan yang diharapkan. Salah satu langkah untuk memiliki strategi itu adalah harus menguasai teknik-teknik penyajian yaitu metode mengajar. ${ }^{3}$ Untuk pengembangan variasi pembelajaran, seorang guru tidak asal dalam pemilihan metode pembelajaran. Metode yang digunakan harus tepat untuk penyampaian materi, karena metode mempunyai peran yang besar dalam proses belajar mengajar. Selain itu, tujuan pembelajaran juga akan tercapai dengan penggunaan metode yang tepat.

Peningkatan prestasi belajar siswa dibutuhkan suatu variasi metode pembelajaran supaya bisa menarik perhatian siswa. Salah satu metode pembelajaran yang bisa diterapkan adalah metode scramble. Metode scramble merupakan salah satu metode pembelajaran kooperatif yang melibatkan kejelian pikiran dan pengetahuan untuk menyusun kata atau frase. Metode ini bisa mendorong peserta didik untuk berfikir secara aktif dengan materi (kata teracak) yang diberikan oleh guru. Metode ini diharapkan dapat membantu siswa dalam memahami materi pelajaran sehingga prestasi belajar siswa akan meningkat.

Dalam proses belajar mengajar guru mempunyai tugas untuk mendorong, membimbing, dan memberi fasilitas belajar bagi peserta didik untuk mencapai tujuan. Guru mempunyai tanggung jawab untuk membantu perkembangan peserta didik dan mengamati segala sesuatu yang terjadi di dalam kelas. ${ }^{4}$ Tugas lain yang dihadapi oleh guru adalah menentukan prestasi yang diharapkan dari siswa dalam mencapai tujuan yang telah dirumuskan secara operasional.

Di dalam materi SKI harus ditekankan pada penguatan-penguatan yang terjadi di dalam sejarah masa lalu. Pada umumnya, pelajaran tentang sejarah berkaitan dengan daya ingat dan pengetahuan peserta didik yaitu menelaah tentang asal-usul, perkembangan, peranan kebudayaan/peradaban Islam dan para tokoh yang berprestasi dalam sejarah Islam di masa lampau, mulai dari sejarah masyarakat Arab pra-Islam, sejarah kelahiran dan kerasulan Nabi Muhammad SAW, sampai masa Khulafaurrasyidin. Untuk itu, seorang guru harus dituntut kreatif dan inovatif dalam menyampaikan materi pelajaran guna merangsang daya ingat dan pengetahuan peserta didik. Maka dari itu, metode scramble merupakan salah satu alternatif metode yang bisa digunakan untuk menyampaikan materi SKI.

${ }^{3}$ Syaiful Bahri Djamarah dan Azwan Zain, Strategi Belajar Mengajar, (Jakarta: PT. Rineka Cipta, 1997), hlm. 84.

${ }^{4}$ Slameto, Belajar dan Faktor-faktor yang Mempengaruhinya, Cet. Ke-2, (Jakarta : Rineka Cipta, 1995), hlm. 97. 
Peneliti menggunakan metode scramble melalui Penelitian Tindakan Kelas (PTK) dengan mengambil sisi positifnya sehingga dapat dijadikan bahan pertimbangan untuk pembelajaran SKI. Penelitian ini bersifat kolaboratif, dimana peneliti melakukan kegiatan pembelajaran bekerja sama dengan guru mata pelajaran sebagai observer. Guru membantu proses observasi dan refleksi dalam kegiatan pembelajaran pada tiap siklus.

Pada penelitian ini dapat terdapat tiga rumusan masalah. Pertama bagaimana perencanaan pembelajaran SKI dengan metode scramble di kelas V MI Al-Iman Sorogenen? Kedua bagaimana pelaksanaan pembelajaran SKI dengan metode scramble di kelas V MI Al-Iman Sorogenen? Ketiga apakah penerapan metode scramble dapat meningkatkan prestasi belajar SKI di kelas V MI Al-Iman Sorogenen?

\section{METODE PENELITIAN \\ Desain dan Jenis Penelitian}

Jenis penelitian ini adalah penelitian tindakan kelas (classroom action research). Penelitian ini menggunakan metode kualitatif didukung dengan data kuantitatif. Desain penelitian yang digunakan adalah model yang dikemukakan oleh Kemmis dan Taggart. ${ }^{5}$

\section{Subjek dan Objek Penelitian}

Subjek penelitiannya adalah siswa kelas $\mathrm{V}$ semester 2 tahun pelajaran 2012/2013 MI Al-Iman Sorogenen. Objek penelitian dalam penelitian ini adalah penerapan metode scramble dalam pembelajaran SKI, dilihat dari kemajuan siswa dalam mengerjakan soal-soal pre test dan post test pada tiap siklusnya, serta peningkatan prestasi belajar siswa setelah diterapkan metode scramble.

Pada kelas V MI Al-Iman Sorogenen, jumlah siswa adalah 15 dengan rincian 12 orang siswa laki-laki dan 3 orang siswa perempuan.

\section{Populasi Penelitian}

Populasi adalah keseluruhan subjek penelitian. ${ }^{6}$ Di dalam penelitian ini adalah siswa kelas V MI Al-Iman Sorogenen tahun pelajaran 2012/2013.

${ }^{5}$ Rochiati Wiriaatmadja, Metode Penelitian Tindakan Kelas: Untuk Meningkatkan Kinerja Guru dan Dosen, Cet. 3, (Bandung, PT. Remaja Rosda Karya, 2007), hlm. 66.

${ }^{6}$ Suharsimi Arikunto, Prosedur Penelitian: Suatu Pendekatan Praktik, Cet. XIII, Ed. VI, (Jakarta : Rineka Cipta, 2006), hlm. 130. 


\section{Waktu dan Tempat Penelitian}

Penelitian dilakukan di MI Al-Iman Sorogenen Timbulharjo Sewon Bantul Yogyakarta. Penelitian tindakan dilaksanakan di kelas V, pada semester genap tahun pelajaran 2012/2013.

\section{Langkab-langkab Penelitian Tindakan}

Penelitian tindakan kelas ini dilaksanakan dalam 2 siklus. Secara terperinci prosedur penelitian tindakan kelas yang dilakukan sesuai dengan desain penelitian yang akan digunakan.

\section{Teknik dan Instrumen Pengumpulan Data}

Teknik Pengumpulan Data

Observasi

Di dalam observasi ini, peneliti terlibat langsung dengan kegiatan seharihari dengan apa yang diamati sebagai sumber data penelitian. Sambil melakukan pengamatan, peneliti melakukan apa yang dikerjakan oleh sumber data. ${ }^{7}$

\section{Wawancara}

Wawancara yang digunakan yaitu berupa pembicaraan secara informal. Pertanyaan wawancara berjalan secara spontanitas sehingga hubungan pewawancara dengan yang terwawancara di dalam suasana biasa dan berjalan seperti pembicaraan dalam kehidupan sehari-hari. ${ }^{8}$ Wawancara tersebut digunakan untuk memperoleh data berupa sejarah berdiri MI Al-Iman, struktur organisasi, dan sebagainya.

\section{Dokumentasi}

Teknik dokumentasi ini digunakan untuk mendapatkan data yang sifatnya tertulis. ${ }^{9}$ Seperti halnya sejarah berdirinya MI Al-Iman Sorogenen, struktur organisasi, dan data-data yang ada di MI Al-Iman Sorogenen. Dokumentasi merupakan pelengkap dari penggunaan metode observasi dan wawancara.

${ }^{7}$ Sugiyono, Metode Penelitian Kuantitatif Kualitatif dan R\&D, (Bandung: Alfabeta, 2010), hlm. 227.

${ }^{8}$ Lexy J. Moleong, Metodologi Penelitian Kualitatif, Cet. XX, Ed. Revisi, (Bandung: PT. Remaja Rosdakarya, 2010), hlm. 187.

${ }^{9}$ Suharsimi Arikunto, Prosedur Penelitian..., hlm. 231. 
Tes

Tes adalah latihan serta alat lain yang digunakan untuk mengukur keterampilan, pengetahuan inteligensi, dan kemampuan yang dimiliki seseorang. Tes yang digunakan dalam penelitian ini adalah tes prestasi berupa soal pre test dan post test. Tes ini digunakan untuk mengukur kemampuan siswa dalam mempelajari materi SKI.

Instrumen Pengumpulan Data

Data yang diambil dalam penelitian ini meliputi penilaian-penilaian selama proses pembelajaran yaitu penerapan metode dan kegiatan belajar. Instrumen yang digunakan dalam penelitian ini antara lain :

Rencana Pelaksanaan Pembelajaran (RPP) dan silabus mata pelajaran SKI kelas V MI Al-Iman Sorogenen.

LKS (lembar kerja siswa).

Kartu soal dan kartu jawaban yang sudah di acak hurufnya. d. Soal pre test dan post test.

Lembar Observasi.

Lembar observasi digunakan untuk memperoleh data terkait dengan aktivitas siswa selama proses pembelajaran berlangsung. Format lembar observasi berbentuk format centang.

\section{Teknik Analisis Data}

Analisis data dilakukan sejak data diperoleh dari hasil observasi oleh peneliti. Selanjutnya dari hasil penelitian dianalisis secara deskriptif, yaitu statistic yang digunakan untuk menganalisis data dengan cara mendeskripsikan atau menggambarkan data yang telah terkumpul tanpa bermaksud membuat kesimpulan yang berlaku generalisasi. ${ }^{10}$ untuk umum atau Analisis data dilakukan dengan tahap-tahap sebagai berikut :

\section{Analisis Data Pelaksanaan Pembelajaran}

Data yang dianalisis dalam pelaksanaan pembelajaran tersebut terdapat dalam lembar observasi yang mencakup aktivitas guru, aktivitas siswa, dan proses pembelajaran yang dianalisis secara deskriptif.

\section{Analisis Prestasi Belajar Siswa}

Data yang digunakan untuk mengukur prestasi belajar siswa yaitu dari data pre test dan post test setiap siklusnya dicari Effect Size, yaitu hasil selisih

${ }^{10}$ Sugiyono. Metode Penelitian Kuantitatif ...hlm. 147. 
rata-rata post test siklus 1 dan post test siklus 2 . Siswa dikatakan meningkat prestasi belajarnya jika terjadi peningkatan persentase rata-rata hasil tes tersebut.

\section{Analisis Data untuk Mendeskripsikan Aktivitas Siswa}

Analisis data untuk mendeskripsikan aktivitas siswa berdasarkan pengamatan yang dilakukan oleh observer. Pengamatan aktivitas belajar siswa dilakukan menggunakan lembar observasi.

\section{Kesimpulan}

Data yang diperoleh kemudian disimpulkan berdasarkan hasil setelah dianalisis dengan memperhatikan hasil prestasi belajar yang dicapai pada siklus 1 dan siklus 2, yang menerapkan metode scramble. Hasil prestasi belajar diperhatikan dari sebelum materi diajarkan dan setelah materi diajarkan untuk mengetahui peningkatan prestasi belajar.

\section{HASIL PENELITIAN}

Penelitian tindakan kelas tentang penerapan metode scramble untuk meningkatkan prestasi belajar Sejarah Kebudayaan Islam di MI Al-Iman telah terlaksana dalam 2 siklus. Kegiatan didalam 2 siklus tersebut dipaparkan dalam pembahasan ini dengan rincian sebagai berikut :

\section{Siklus 1}

Dalam Siklus 1 terdiri dari dua kali pertemuan yaitu pertemuan pertama dilaksanakan pada hari Kamis, 10 Januari 2013, pukul 11.00-12.10 WIB. Pertemuan kedua dilaksanakan pada hari Kamis, 17 Januari 2013, pukul 11.0012.10.

Pada pertemuan pertama, guru mengajar sesuai yang ada didalam RPP. Guru masuk kelas, membuka pembelajaran dengan salam, berdoa dan mengabsen siswa. Setelah itu guru menyinggung sedikit tentang materi yang akan disampaikan dan melakukan tanya jawab. Selanjutnya, guru membagikan lembar pre test untuk mengetahui kesiapan siswa dalam pembelajaran dan dikerjakan kurang lebih selama 10 menit. Guru menyajikan materi tentang sebab-sebab terjadinya Fathul Makkah dengan metode ceramah dan tanya jawab. Setelah selesai menyampaikan materi, guru mempersilahkan siswa untuk bertanya seputar materi yang belum dipahami oleh siswa. Kegiatan tanya jawab selesai, kemudian guru dan siswa bersama-sama menyimpulkan materi yang sudah disampaikan.

Pertemuan kedua, guru membuka kegiatan pembelajaran dengan salam, berdo'a dan mengabsen siswa. Setelah itu, guru menjelaskan tentang 
penggunaan metode yang digunakan dalam pembelajaran yaitu metode scramble. Siswa diberikan kartu soal dan kartu jawaban (scramble) untuk dikerjakan. Selesai mengerjakan, guru melakukan tanya jawab terkait soal yang telah diberikan untuk mamancing daya pikir siswa. Setelah itu, guru membagikan soal post test kepada siswa yang digunakan untuk mengetahui keberhasilan pembelajaran yang telah dilaksanakan. Pada siklus 1, observer mengamati pelaksanaan pembelajaran, aktivitas siswa, dan tes yang telah dilakukan berupa pre test dan post test.

\section{Siklus 2}

Dalam Siklus 2 terdiri dari dua kali pertemuan yaitu pada hari Kamis, 31 Januari 2013 pukul 11.00-12.10 WIB dan Kamis, 7 Februari 2013 pukul 11.00-12.10 WIB.

Seperti yang telah dilaksanakan pada siklus 1, pada pertemuan pertama, guru mengajar sesuai yang ada didalam RPP. Guru masuk kelas, membuka pembelajaran dengan salam, berdoa dan mengabsen siswa. Setelah itu guru melakukan tanya jawab seputar materi pada pertemuan lalu. Selanjutnya, guru membagikan lembar pre test untuk mengetahui kesiapan siswa dalam pembelajaran dan dikerjakan kurang lebih selama 10 menit. Guru menyajikan materi Fathul Makkah dengan metode ceramah dan tanya jawab. Setelah selesai menyampaikan materi, guru mempersilahkan siswa untuk bertanya seputar materi yang belum dipahami oleh siswa. Kegiatan tanya jawab selesai, kemudian guru dan siswa bersama-sama menyimpulkan materi yang sudah disampaikan.

Pertemuan kedua, guru membuka kegiatan pembelajaran dengan salam, berdo'a dan mengabsen siswa. Setelah itu, guru menjelaskan tentang penggunaan metode yang digunakan dalam pembelajaran yaitu metode scramble. Guru membagikan kartu soal dan kartu jawaban (scramble) untuk dikerjakan siswa. Selesai mengerjakan, guru melakukan tanya jawab terkait soal yang telah diberikan. Setelah itu, guru membagikan soal post test kepada siswa untuk mengetahui keberhasilan pembelajaran yang telah dilaksanakan. Pada siklus 2, observer mengamati pelaksanaan pembelajaran, aktivitas siswa, dan tes yang telah dilakukan berupa pre test dan post test. Berdasarkan hasil pengamatan yang dilakukan oleh guru dan observer, pelaksanaan pembelajaran yang terlaksana pada siklus 1 dan siklus 2 adalah gabungan dari beberapa metode sebagai berikut:

\section{Metode Scramble}

Metode scramble merupakan permainan yang digemari oleh semua orang karena permainan ini melibatkan kejelian pikiran dan pengetahuan untuk 
menyusun kata atau frase. Metode ini bisa mendorong peserta didik untuk berfikir secara aktif dengan materi (kata teracak) yang ada. ${ }^{11}$

Dengan metode scramble ini, siswa akan lebih paham untuk mamahami suatu materi dalam mata pelajaran Sejarah Kebudayaan Islam. Siswa juga akan lebih aktif untuk berusaha menemukan jawaban. Metode scramble termasuk metode pembelajaran kooperatif yaitu membutuhkan kerjasama dengan orang lain.

\section{Metode Diskusi}

Metode Diskusi merupakan interaksi antara siswa dan siswa atau interaksi siswa dengan guru untuk menganalisis dan memecahkan masalah. ${ }^{12}$ Didalam penelitian ini, metode diskusi sangat berperan dalam penerapannya bersama metode scramble karena pada penelitian ini, metode scramble merupakan bagian dari diskusi.

Metode diskusi erat kaitannya dengan metode lainnya, misalnya ceramah, karya wisata dan lain-lain karena metode diskusi ini adalah begian yang terpenting dalam memecahkan suatu masalah. ${ }^{1{ }^{4}}{ }^{46}$ Di dalam penerapan metode scramble, metode diskusi ini bertujuan untuk membantu siswa dalam mencari alternatif jawaban berdasarkan pertimbangan yang seksama dengan teman kelompoknya. Selain itu, tujuan lain penggunaan metode diskusi bersamaan dengan metode scramble ini adalah untuk mendorong siswa mengembangkan pikirannya untuk memecahkan masalah bersama.

\section{Metode Tanya Jazeab}

Metode tanya jawab adalah cara penyajian pelajaran dalam bentuk pertanyaan yang harus dijawab oleh dan dari guru kepada siswa atau siswa kepada guru. ${ }^{14}$ Metode ini dapat merangsang siswa untuk berfikir mencoba mencari jawaban dari materi pelajaran yang telah didapatkan. Pada penelitian ini, metode tanya jawab dilakukan setelah mengerjakan soal dengan metode scramble. Di dalam pembelajaran pada tiap siklus, guru mengajukan pertanyaanpertanyaan terkait dengan materi pelajaranyang telah disampaikan dan bertanya seputar soal yang baru saja dikerjakan.

Pada kegiatan tanya jawab ini, bukan hanya guru yang bertanya kepada siswa, tetapi siswa bertanya kepada guru terkait materi yang belum jelas.

${ }^{11}$ Hanafi, Pembelajaran Sejarah..., hlm. 207

${ }^{12}$ Martinis Yamin, Desain Pembelajara..., hlm. 158.

${ }^{13}$ Zakiah Daradjat, dkk, Metodik Khusus Pengajaran Agama Islam (Jakarta : PT. Bumi Aksara, 2004), hlm. 104

${ }^{14}$ Umi Zulfa, Strategi Pembelajaran, ..., hlm.25. 
Metode ini diterapkan untuk memusatkan perhatian siswa dan merangsang ingatan siswa dan mengembangkan daya pikir.

\section{Metode Ceramah}

Metode ceramah adalah cara penyajian pelajaran yang dilakukan oleh guru dengan penuturan atau penjelasan lisan secara langsung terhadap siswa. ${ }^{15}$ Dalam proses belajar mengajar, guru tidak lepas dari penggunaan metode ceramah. Dengan metode ceramah, guru dapat dengan mudah menguasai kelas sehingga siswa bisa lebih terkontrol. Guru juga dapat memberi informasi sebanyak-banyaknya kepada siswa tentang materi Fathul Makkah. Kegiatan pembelajaran pada siklus 1, proses pembelajaran berjalan sesuai dengan RPP yang telah dibuat. Kegiatan pembelajaran terlihat masih belum sempurna, siswa masih banyak yang bingung dan belum paham dengan metode scramble yang diterapkan. Walaupun ada siswa yang paham, tetapi itu hanya sebagian kecil saja. Hasil refleksi pada siklus 1 tentang penggunaan metode scramble adalah sebaiknya guru memberikan/ menyisipkan penggunaan metode tersebut setelah materi pelajaran disampaikan beberapa menit agar siswa lebih paham dalam penggunaan metode scramble tersebut. Guru memberikan beberapa soal beserta jawabannya dipapan tulis, selanjutnya siswa yang ingin mengerjakan, dipersilahkan maju ke depan untuk mengerjakan soal yang diberikan. Sehingga siswa lebih paham penggunaannya dalam menyelesaikan soal. Selain itu, guru harus lebih menguasai materi yang akan diajarkan.

Untuk kegiatan pembelajaran pada siklus 2 sudah bisa berjalan sesuai dengan apa yang diharapkan, ini terbukti dengan sikap antusias siswa dalam mengikuti pelajaran dan nilai post test untuk siklus 2 ini meningkat dibandingkan siklus 1. Peningkatan ini terjadi karena langkah-langkah pembelajaran yang dilaksanakan pada siklus 1, diperbaiki pada siklus 2 .

Penerapan metode scramble ini dapat meningkatkan prestasi belajar siswa. Ini terbukti dengan adanya nilai pre test dan post test siklus 1 dan siklus 2 .

Tabel 1. Peningkatan Nilai Pre Test dan Post Test Siklus 1 dan Siklus 2

\begin{tabular}{|c|c|c|c|c|}
\hline & \multicolumn{2}{|c|}{ Siklus 1} & \multicolumn{2}{|c|}{ Siklus 2} \\
\hline & Pre Test & Post Test & Pre Test & Post Test \\
\hline Rata-rata & 42 & 71,3 & 48 & 78,6 \\
\hline Effect Size & & & & \\
\hline
\end{tabular}

${ }^{15}$ Ibid, hlm. 26. 
Dari tabel di atas, terlihat bahwa siklus 1 ada peningkatan nilai rata- rata pre test dan nilai rata-rata post test. Nilai rata-rata pre test yaitu 42 dan nilai rata-rata post test yaitu 71,3. Pada siklus 2 juga terlihat peningkatan nilai ratarata pre test dan nilai rata-rata post test. Nilai rata-rata pre test yaitu 48 dan nilai rata-rata post test yaitu 78,6 . Selisih nilai rata-rata (effect size) nilai post test siklus 1 dan siklus 2 yaitu sebesar 7,3.

Tabel 2. Persentase Peningkatan Nilai Prestasi Siklus 1 dan Siklus 2

\begin{tabular}{lcccc}
\hline & \multicolumn{2}{c}{ Pre Test } & \multicolumn{2}{c}{ Post Test } \\
\cline { 2 - 5 } & Nilai Rata- rata & Persentase & Nilai Rata- rata & Persentase \\
\hline Siklus 1 & 42 & 46,6 & 71,3 & 53,3 \\
Siklus 2 & 48 & 53,3 & 78,6 & 80 \\
Peningkatan & 6 & 6,7 & 7,3 & 26,7 \\
\hline
\end{tabular}

Pada tabel di atas menunjukkan persentase peningkatan nilai pre test dan post test siklus 1 dan siklus 2. Siklus 1 menunjukkan peningkatan dari nilai pre test $46,6 \%$ menjadi $53,3 \%$ pada post test. Siklus 2 menunjukkan peningkatan dari nilai pre test 53,3\% menjadi $80 \%$. Peningkatan nilai rata- rata pre test siklus 1 dan pre test siklus 2 adalah 6 dengan persentase 6,7\%. Sedangkan nilai rata-rata post test siklus 1 dan siklus 2 adalah 7,3 dengan persentase $26,7 \%$.

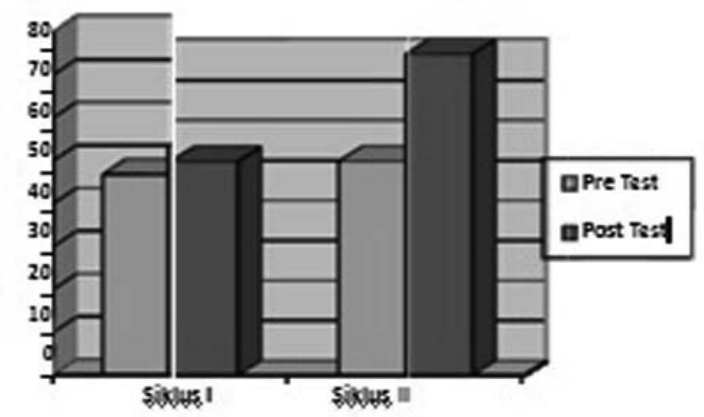

\section{Gambar 1. Grafik Peningkatan Prestasi Belajar SKI}

Berdasarkan grafik di atas, penerapan metode scramble pada mata pelajaran SKI telah berhasil. Terlihat dari hasil nilai rata-rata pre test dan nilai rata-rata post test. Nilai rata-rata pre test dan nilai rata-rata post test dari siklus 1 ke siklus 2 menunjukan peningkatan prestasi yang cukup signifikan. 


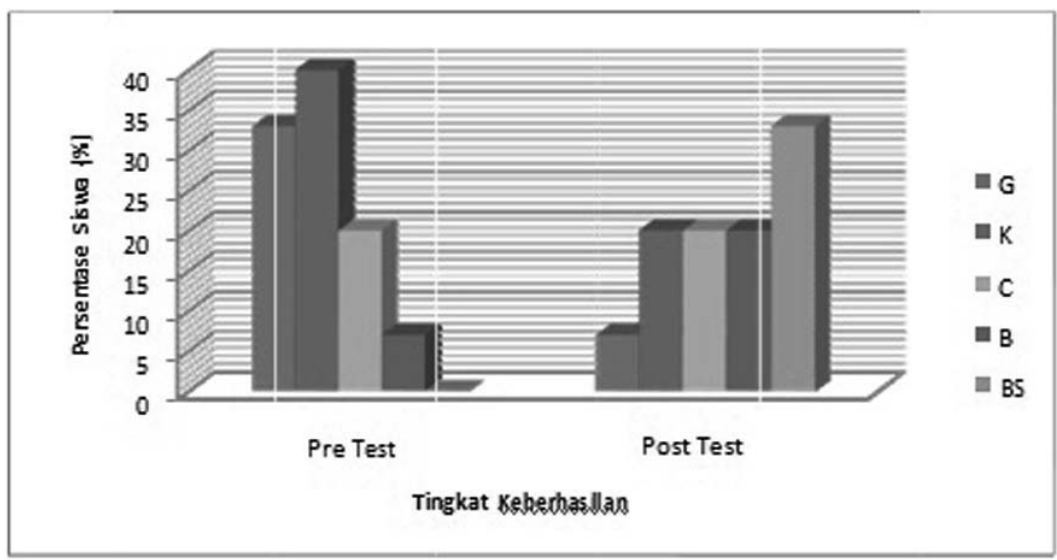

Gambar 2. Grafik Persentase Tingkat Penguasaan Materi Pelajaran Sejarah Kebudayaan Islam Siklus 1.

Dari grafik di atas, dapat terlihat bahwa penguasaan materi saat dilakukan pre test pada siklus 1 untuk kategori baik dan baik sekali menunjukkan angka yang sangat rendah dibandingkan dengan katerogi gagal, kurang, dan cukup. Setelah dilakukan penyampaian materi dan diterapkannya metode scramble pada materi Fathul Makkah, siswa mengalami peningkatan penguasaan materi. Ini terbukti dengan nilai post test untuk siklus 1 mengalami peningkatan yang cukup signifikan pada kategori baik dan baik sekali.

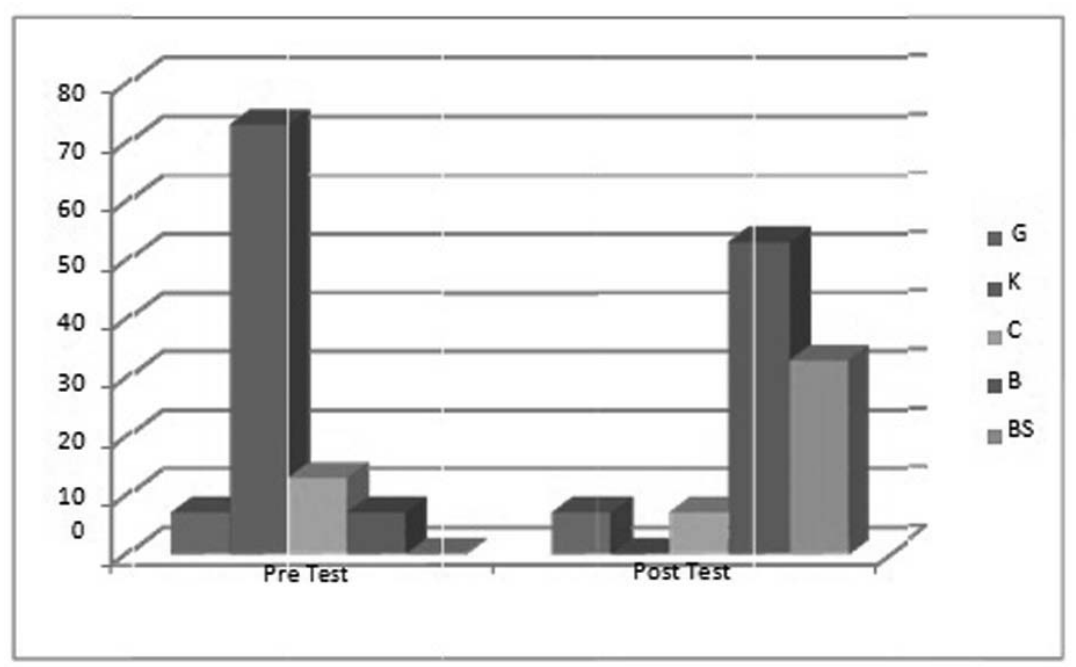

Gambar 3. Grafik Persentase Tingkat Penguasaan Materi Pelajaran Sejarah Kebudayaan Islam Siklus 2. 
Dari grafik di atas, dapat terlihat bahwa penguasaan materi saat dilakukan pre test pada siklus 2 untuk kategori baik dan baik sekali menunjukkan angka yang sangat rendah dibandingkan dengan katerogi gagal, kurang, dan cukup. Setelah dilakukan penyampaian materi dan diterapkannya metode scramble pada materi Fathul Makkah, siswa mengalami peningkatan penguasaan materi. Ini terbukti dengan nilai post test untuk siklus 2 juga mengalami peningkatan yang cukup signifikan pada kategori baik dan baik sekali.Secara keseluruhan, metode scramble untuk pembelajaran Sejarah Kebudayaan Islam yang diterapkan di kelas V MI Al-Iman Sorogenen berlangsung dengan baik dan dapat memberikan hasil. Peningkatan penguasaan materi terlihat pada kategori baik. Dari kedua siklus, dapat diketahui bahwa penerapan metode scramble dapat meningkatkan prestasi belajar Sejarah Kebudayaan Islam kelas V MI Al-Iman Sorogenen. Dari grafik di atas, dapat terlihat bahwa penguasaan materi saat dilakukan pre test pada siklus 2 untuk kategori baik dan baik sekali menunjukkan angka yang sangat rendah dibandingkan dengan katerogi gagal, kurang, dan cukup. Setelah dilakukan penyampaian materi dan diterapkannya metode scramble pada materi Fathul Makkah, siswa mengalami peningkatan penguasaan materi. Ini terbukti dengan nilai post test untuk siklus 2 juga mengalami peningkatan yang cukup signifikan pada kategori baik dan baik sekali.Secara keseluruhan, metode scramble untuk pembelajaran Sejarah Kebudayaan Islam yang diterapkan di kelas V MI Al-Iman Sorogenen berlangsung dengan baik dan dapat memberikan hasil. Peningkatan penguasaan materi terlihat pada kategori baik. Dari kedua siklus, dapat diketahui bahwa penerapan metode scramble dapat meningkatkan prestasi belajar Sejarah Kebudayaan Islam kelas V MI Al-Iman Sorogenen.

\section{KESIMPULAN}

Hasil penelitian pada siswa menunjukkan bahwa:

Perencanaan metode scramble yang dilaksanakan pada pembelajaran Sejarah Kebudayaan Islam kelas V MI Al-Iman Sorogenen berjalan dengan lancar dimulai dari pembuatan Rencana Pelaksanaan Pembelajaran (RPP), pembuatan kartu soal dan kartu jawaban, membuat lembar pre test dan post test, dan membuat lembar observasi.

Metode scramble dapat dilaksanakan dan diterapkan dalam pembelajaran Sejarah Kebudayaan Islam kelas V MI AL-Iman Sorogenen.

Prestasi belajar siswa kelas V MI AL-Iman Sorogenen pada mata pelajaran Sejarah Kebudayaan Islam diakhir penelitian setelah melakukan pembelajaran dengan metode scramble, mengalami peningkatan. Peningkatan 
prestasi belajar siswa menunjukkan rata-rata nilai pre test siklus 1 adalah 46,6\% meningkat pada post test menjadi 53,33\%. Sedangkan pada siklus 2 menunjukkan adanya peningkatan prestasi belajar dari rata-rata nilai pre test $53,33 \%$ meningkat pada post test menjadi $80 \%$. Jadi, peningkatan prestasi belajar SKI kelas V MI Al-Iman Sorogenen berdasarkan hasil post test adalah $26,7 \%$.

\section{DAFTAR PUSTAKA}

Agus Suprijono, 2010, Cooperative Learning, Cet. Ke-5, Yogyakarta: Pustaka Pelajar

Anas Sudjono, 2005, Pengantar Statistik Pendidikan, Jakarta: Rajawali Press Anita Lie, 2004, Cooperative Learning: Mempraktikkan Cooperative Learning di Ruang-Ruang Kelas, Cet. Ke-4, Jakarta: Grasindo

Daryanto, 2005, Evaluasi Pendidikan, Jakarta: Rineka Cipta

Dewi Salma, 2009, Prinsip Disain Pembelajaran, Jakarta: Kencana Prenada

Media Group

Dimyati dan Mudjiono, 2010, Belajar dan Pembelajaran, Jakarta: Rineka Cipta

Djemari Mardapi, 2008. Teknik Penyusunan Instrumen Tes dan Non Tes, Yogyakarta: Mitra Cendikia

Ginnis, Paul, 2008, Trik dan Taktik Mengajar: Strategi Meningkatkan Pencapaian Pengajaran di Kelas, Terjem. oleh Wasi Dewanto, Cet. Ke-1, Jakarta: PT. Indeks

Hanafi, 2009, Pembelajaran Sejarab Kebudayaan Islam, Jakarta: Direktorat Jenderal Pendidikan Islam Depag RI

Isjoni, 2010, Pembelajaran Kooperatif Meningkatkan Kecerdasan Komunikasi Antar Peserta Didik, Yogyakarta: Pustaka Pelajar

Kharisma Rahmawati, 2010, Penerapan Metode Cooperative Learning Tipe Student Teams Achievement Divisions (STAD) Sebagai Upaya Meningkatkan Minat dan Partisipasi Siswa dalam Pembelajaran Aqidah Akblak kelas VIII A SMP Muhammadiyah Imogiri, Skripsi, Yogyakarta : Fakultas Tarbiyah, Universitas Islam Negeri Sunan Kalijaga

Lexy J, Moleong, Metodologi Penelitian Kualitatif, Cet. XX, Ed. Revisi, Bandung: PT. Remaja Rosdakarya

Martinis Yamin, 2007, Desain Pembelajaran Berbasis Tingkat Satuan Pendidikan, Jakarta : Gaung Persada Press. 
Nana Sudjana, 2010, Dasar-dasar Proses Belajar Mengajar, Cet. Ke. 11, Bandung: Sinar Baru Algesindo , 2010, Penilaian Hasil Proses Belajar Mengajar, Cet. Ke-15, Bandung: PT. Remaja Rosdakarya

Ngalim Purwanto, 2010, Prinsip-prinsip dan Teknik Evaluasi Pengajaran, Cet. Ke-16, Bandung: PT. Remaja Rosdakarya

Oemar Hamalik, 2006, Perencanaan Pengajaran Berdasarkan Pendekatan Sistem, Cet. Ke-4, Jakarta: Bumi Aksara

Prasetya Dewi Anjarsari, 2010, Efektivitas Pembelajaran Matematika malalui Metode Make A Match dan Scramble Terhadap Pemahaman Konsep dan Keaktifan Belajar Siswa VII Mts Ma'arif NU 1 Wangon-Banyumas, Skripsi, Yogyakarta: Fakultas Sains dan Teknologi, Universitas Islam Negeri Sunan Kalijaga

Rochiati Wiriatmaja, 2007, Metode Penelitian Tindakan Kelas: Untuk Meningkatkan Kinerja Guru dan Dosen, Cet. Ke-3. Bandung: PT. Remaja Rosda Karya

Silberman, Mel, 2005, Active Learning: 101 Strategi Pembelajaran Aktif, Terjem. oleh Sarjuli, dkk, Cet. Ke-3, Yogyakarta: Yappendis

Slameto, 1995, Belajar dan Faktor-faktor yang Mempengarubinya, Cet. Ke-2, Jakarta: Rineka Cipta

Sugiyono, 2010, Metode Penelitian Kuantitatif Kualitatif dan $R \ll D$, Bandung: Alfabeta

Suharsimi Arikunto, 2006, Prosedur Penelitian: Suatu Pendekatan Praktik, Cet.XIII. Ed. VI, Jakarta: Rineka Cipta , 2011, Dasar-dasar Evaluasi Pendidikan, Cet. Ke-11, Jakarta: Bumi Aksara

Suyatno, 2005, Permainan Pendukung Pembelajaran Babasa dan Sastra, Jakarta: PT. Grasindo

Syaiful Bahri Djamarah dan Aswan Zain, 1997, Strategi Belajar Mengajar, Jakarta: PT Rineka Cipta

Tim Penyusun Kamus Pusat Pembinaan dan Pengembangan Bahasa, 2002, Kamus Besar Bahasa Indonesia, Ed. Ke-3, Cet. Ke-2, Jakarta: Balai Pustaka

Umi Zulfa, 2010, Strategi Pembelajaran, Ed. Revisi, Cilacap: A. Ghazali Press www. kolegaku.wordpress.com, diakses tanggal 6 Agustus 2012, pukul 10.25 WIB Zakiyah Darajat, dkk, 2004, Metodik Khusus Pengajaran Agama Islam, Jakarta: PT. Bumi Aksara. 